\title{
Evaluating the Effect of the Economic Factors that Affect the Crop Price on the Continuation of Agriculture in Wadi Al-Dawasir, Saudi Arabia
}

\author{
Abdulaziz M. Alqarawy, Ahmed S. Kamis, Jalal M. BaSahi and Mohammed I. Al Saud* \\ Department of Hydrology and Water Resources Management, Faculty of Meteorology, \\ Environment and Arid Land Agriculture, King Abdulaziz University, Jeddah, and *Ministry of \\ Environment, Water and Agriculture, Saudi Arabia \\ alqarawy86@gmail.com
}

\begin{abstract}
The aim of this study is to evaluate the impact of the economic factors that affect the price of crops on the continuation of agriculture in Wadi Al-Dawasir. A field survey is conducted covering 39 farms, including all crops. A random stratified sampling method is used to collect the data. The results showed that farmer pays for groundwater between 0.13 to $0.41 \mathrm{SR} / \mathrm{M} 3$. The study concluded that lifting the governmental subsidies on diesel will stop the cultivation of wheat and Rhodes and will affect the cultivation of Alfalfa. However, vegetable and date crops will be less affected due to their high profit.
\end{abstract}

Keywords. Wadi Al-Dawasir, Saudi Arabia, Agriculture, irrigation cost, Ground Water cost.

\section{Introduction}

Wadi Al-Dawasir is one of the largest agricultural centers in Kingdom of Saudi Arabia. The estimated amount of groundwater drawn for agricultural purposes was near to 2051 million cubic meters in 2005, which is about $10 \%$ of the total groundwater drawn for agricultural purposes in Kingdom of Saudi Arabia (Gesellschaft and Dornier, 2010 a). There was no concern about the use of water for agricultural purposes in the Kingdom of Saudi Arabia before 1970 (i.e. before the emergence of the oil industry and rapid agricultural expansion). However, the rapid expansion or so-called "agricultural revolution" led to the intensive use of irrigation systems that consume large quantities of water without any restrictions, which affect the future availability of nonrenewable water (Kim and Der Beek, 2018).
Total water consumption in Saudi Arabia is estimated at 24 billion cubic meters per year (Ouda, 2013). Consumption of the urban sector (municipal and industrial) compose $17 \%$ of total demand while the agricultural sector compose $83 \%$ of the total water demand in Saudi Arabia (Alhassan et al., 2015). Consequently, any policy aim to improve the sustainability of water resources will not ignore the agricultural dimension (Napoli et al., 2016). There is a strong relationship between water, energy and food, as inefficient use of any of the three resources can adversely affect other suppliers, which require a comprehensive approach to managing these resources (Napoli and Téllez, 2016). Thus any improvement in mitigating water consumption will result in energy savings, especially when irrigation water is used to replace desalinated water (Napoli et al., 2016). 
One of the main reasons for the failure of water management to achieve efficiency is that water is provided free of charge (or free commodity) or at least the economic value of water is not assessed. The fourth principle of Dublin International Water and Environment Conference in 1992 states that "water management as an economic commodity is an important mean of achieving efficient use and encouraging the conservation and protection of water resources (Global Water Partnership, 2000). The most important factors influencing the change in water demand response in the agricultural sector (demand flexibility) are: water price, water cost from alternative source, water price ratio for agricultural production cost, ability to change crop type, ability to change irrigation methods, Agricultural land area and irrigation technologies currently used (Cornish et al., 2004). Farmers do not cultivate Crops with high water efficiency and use unguided irrigation methods for water consumption in case that water prices are cheap (Ray, 2002).

Wadi Al-Dawasir is one of the major irrigation water abstraction from Al-Wajid Confined aquifer (Non-renewable groundwater). Agriculture in the Wadi AlDawasir area consists of technically highly developed farm enterprises that operate modern pivot irrigation system. The size of the centre pivot ranges from 30 to 60 ha with farms managing hundreds of them with the corresponding number of wells. The shallow alluvial aquifers could not sustain the high groundwater abstraction rates for a long time and groundwater level declined dramatically in most areas (Elhag and Bahrawi, 2017). The continuation of the current pumping rates in Wadi Al-Dawasir area will expose water carrier layers in the study area to drought starting in 2020 and after. And in 2050 pumping rates would be below the current values (Gesellschaft and Dornier, 2010 a). This water consumption of non-renewable water for agriculture purposes is unrestricted and lead to an efficient water use. The cost of water incurred by the farmers does not exceed the price of energy required to pump water from the underground, while the prices of energy provided to farmers are heavily subsidized by the government, which makes the cost of water in the agricultural sector very low, that make the farmers uninterested to invest in water conservation methods and increase the efficiency of water use in crop production (such as agricultural reserves and drip irrigation systems).

The town of Wadi Al-Dawasir, is located on the plateau of Najd at Lat $44^{0} \angle 3^{\prime}$ and Lon $20^{0} \_29^{\prime}$ about $300 \mathrm{~km}$ south of the capital city Riyadh (Fig. 1) (Elhag, 2016). Wadi Al-Dawasir area is located about 650 meters above sea level and has a very hot summer and mild winters. The potential annual Evapotranspiration $\left(\mathrm{ET}_{0}\right)$ based on (Panamanian - FAO method) was estimated in at $2628 \mathrm{~mm} /$ year. Evapotranspiration ranges between $4.6 \mathrm{~mm} /$ day in winter and $9.1 \mathrm{~mm} /$ day in summer. Water demand and the average water used for each crop in the study area is estimated by calculating Evapotranspiration rate $\left(\mathrm{ET}_{0}\right)$ using meteorological information and Penith Monteith equation (Gesellschaft and Dornier, 2010 b).

The research aims to study the effect of the economic factors that compose the price of crops on the continuation of agriculture in Wadi Al-Dawasir area in Saudi Arabia, where the structure compose the price of the most important crops in the study area will be studied, in addition to estimating the cost of groundwater extraction system (cost paid by farmers for groundwater). The study of the economic feasibility of ground water use in the cultivation of the most important crops in Wadi Al-Dawasir, and study the effect of the suspension of subsidies on energy prices on the continued cultivation of the most important crops in Wadi Al-Dawasir. 


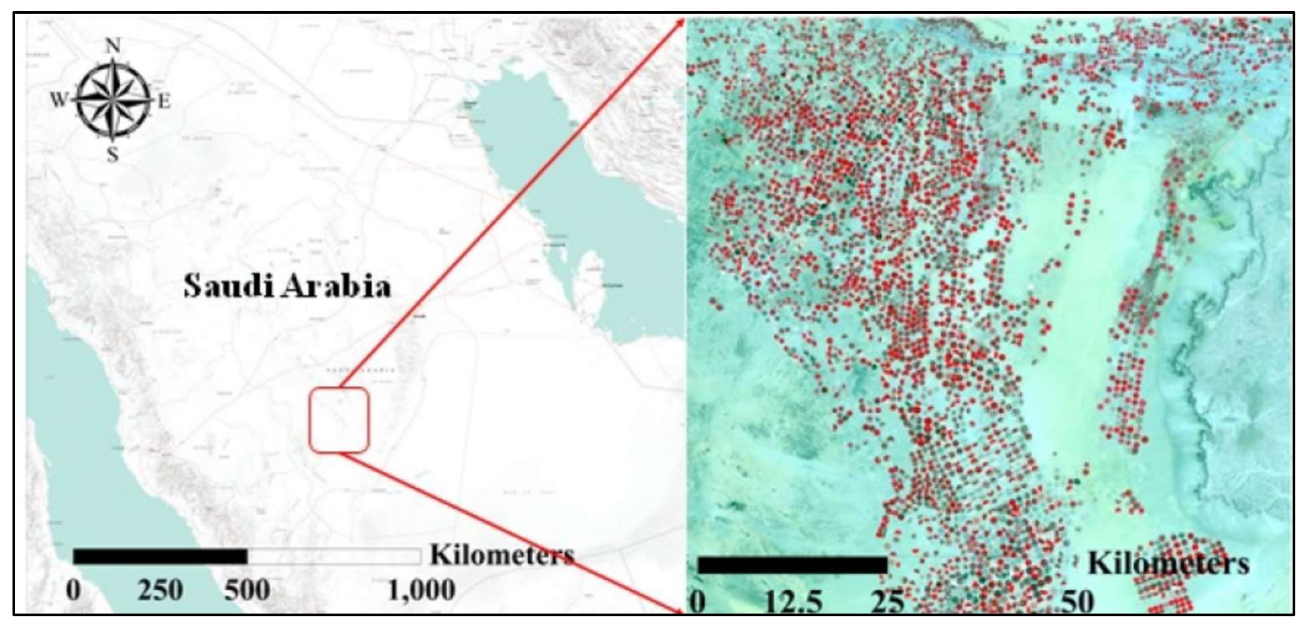

Fig. 1. Location of the study area (Elhag, 2016).

\section{Materials and Methods}

The random and stratified sample method is used to collect data. The sample size is determined according to the suitability of the samples with the crop categories (layer distribution of the samples), so that the samples are not less than 30 samples (Abdelfattah, 2013).

A field survey is conducted for 39 farms in Wadi Al-Dawasir area, including Alfalfa farms, other fodderss farms, dates farms, vegetables and wheat farms. Agricultural crops are divided into five categories, so that the layer distribution of the questionnaires is proportional to the percentage of the agricultural area for each crop category in the study area, according to the latest statistics by the Ministry of Environment, Water and Agriculture, which indicated that the agricultural area in Wadi Al-Dawaser area is composed of Alfalfa farms which represent $47 \%$, other fodderss category $35 \%$, date category $9 \%$, vegetable category $6 \%$, wheat category $3 \%$ of agricultural area in the study area (Ministry of Environment Water \& Agriculture, 2013).

A survey questionnaire is prepared for the field survey. The questionnaire included the following information: (name of the farmer, mean of communication, farm location, farm area, age of agricultural investment, average annual production of the farm, number of harvest times in summer and winter, cost of well construction, purchase of generators and pumps used for pumping ground water, the life span of generators and pumps used for groundwater pumping, type of irrigation system, cost of irrigation system construction, life span of irrigation system, Average annual cost of maintenance, average annual cost of labor, average annual cost of seed purchase, average annual cost of fertilizer purchase, average annual cost of insecticide spraying, annual cost of agricultural land rent, average annual profit of the farmer, average annual income of intermediaries, type of fuel used to operate on-farm generators, average amount of fuel consumed on the farm, (the price paid by farmer for fuel). The researchers assumed that the average well life and life span of generators, pumps and irrigation systems are 20 years (based on the opinion of an agricultural expert in the study area).

Descriptive statistics, a set of statistical methods used to determine the type and size of samples, methods of data collection and presentation, and description of different aspects of data such as the calculation of averages and percentages (Abdelfattah, 2013). 
The averages and percentages for each variable and for each crop were calculated and presented using tables and figures to compare and describe field survey data.

\section{Results and Discussion}

The descriptive analysis of data is based on dividing the crops into five categories: Alfalfa, other fodders, dates, vegetables and wheat. The results of data analysis from the field survey showed that:

\subsection{Analysis of Components of Alfalfa Crop Price}

The price of Alfalfa crop in the markets of the study area is composed of $45 \%$ payments (including all costs paid by the farmer from the beginning of the agricultural project till the harvesting time), while the farmer profits represents $45 \%$ of the crop price, and the profit of commercial intermediaries represent only $10 \%$ of the price of agricultural product. The results showed that the price of Alfalfa crop in the markets of the study area includes $13 \%$ from the maintenance cost, the cost of harvesting equipment is $9 \%$, the cost of seed purchase is $6 \%$, and the cost of the farm rent is $4 \%$, while the cost of energy consumption for water extraction and irrigation are only $3.6 \%$ of the total price of Alfalfa in the market, and labors salaries are $2.6 \%$ of the total price of Alfalfa in the market (Fig. 2).

\subsection{Analysis of Components of Other Fodders Crop Price}

The price of other fodders crops in the markets of the study area are composed of $81 \%$ payments (including the costs paid by the farmers from the beginning of the agricultural project till the harvesting time), while the income of the commercial intermediaries represent $17 \%$, and the farmer only receive $4 \%$ in the study area markets. The cost of the irrigation system and pumps are $15 \%$, the cost of energy consumption is $10 \%$, the cost of harvesting equipment is $9.7 \%$, the cost of purchasing seeds and fertilizer is $5 \%$, and the cost of the pumps and the construction of the well is $3 \%$ of the total price of the other fodders product (Fig. 3).

\subsection{Analysis of Components of Date Crop Price}

The price of date crops in the study area is composed of $29 \%$ payments (including all agricultural costs), while farmer profits is $46 \%$, and intermediaries' income is $25 \%$ of the price of the agricultural product. The cost of renting agricultural land is $13.7 \%$ of the price of the product, while the cost of workers' salaries is about $5.8 \%$, the cost of energy consumption is $3.8 \%$, and the cost of constructing the well is about the same as the average price of date crops (Fig. 4).

\subsection{Analysis of Components of Vegetable Crop Price}

The average price of vegetables in the study area is $13.28 \%$ (including all agricultural costs), $12.49 \%$ for farmer profits, and commercial intermediaries have the big share which is equal to $74.23 \%$ from the vegetables price. This can be explained by the large number of intermediaries who trade in vegetable products commercially until it reach to the consumer. It is worth mentioning that most components of payments do not exceed $1 \%$ of the final product price (except the cost of fertilizer and seeds). The cost of energy consumption is only $1.19 \%$ of the price of vegetables in the study area markets (Fig. 5).

\subsection{Analysis of Components of Wheat Crop Price}

The average price of wheat crop in the markets of the study area compose of $78 \%$ payments (including all agricultural costs), while commercial intermediaries income is $14.5 \%$, and farmer profits are only $7.5 \%$ of the price of the agricultural product. The 
results showed that the cost of fertilizer is $21 \%$ of the product price in the markets of the study area, while the cost of energy consumption is about $18 \%$, the cost of rent is $12.4 \%$, and the cost of maintenance for irrigation system and pumps are $6.4 \%$. The cost of labors and construction of the well are about $4 \%$ each, while the cost of seeds, the rent of harvest equipment, the cost of spraying pesticides and the cost of pumps are only $3 \%$ of the price composition of the wheat product in the study area (Fig. 6).

\subsection{Comparing the Cost of Groundwater Extraction System with Alternative Opportunity Cost}

The study showed that the cost of groundwater extraction system ranged from 0.13 to $0.41 \mathrm{SR}$ per $\mathrm{m}^{3}$ (the value varies according to many factors such as groundwater depth, generator efficiency, crop type, pumping quantity, and irrigated area, etc.). This cost is solely paid by the farmer to obtain water as shown in (Fig. 7). Comparing the cost of the product with the alternative opportunity cost is considered benchmark of economic measurement and comparison. The researcher compared the cost of the groundwater extraction system with the alternative opportunity cost of producing and transporting desalinated seawater to the study area (but the researcher could not obtain information related to these costs from the official authorities or through the published information). Based on that, it been assumed that alternative opportunity cost is equal to the water price (in the upper part of tariff system of National Water Company's bills which equal to SR $6 /$ $\mathrm{m}^{3}$ ) (National Water Company, 2018) .

This comparison leaves no doubt that what farmers pay today does not exceed $5 \%$ of the cost of alternative product (the price of water supplied by the water company to the public and private sector). This comparison showed us the extent of economic waste resulting from the use of this non-renewable groundwater without rationalization of water consumption in a growing profit sector such as the agricultural sector.

\subsection{Comparing Price Components for All Crops}

This study showed the estimations of the economic variables that affect the composition of the price of each main crops in the study area in order to determine the strength of the impact of each component on the crop price. Figure 8 shows the comparison of crop production costs (payments) with the profits of the farmer and intermediaries for the most important crops in Wadi Al-Dawasir area. We have noticed that the vegetable crop is characterized from other crops which the major component of product price is the intermediaries' income. While the composition of the date product price is characterized by higher profits of farmers. The rest of the crops (alfalfa, other fodders and wheat) depend on the bulk of the price structure. Thus, these crops are most affected by changes in energy prices, rising labor wages and taxes enforcement. Vegetable and date crops are highly viable even with high energy prices, labor costs and taxes enforcement, and given that the current price of products is composed mainly of profits shared by the farmers and intermediaries.

\subsection{Estimation of Extraction Cost of Groundwater Used for Crop Irrigation:}

The components of water extraction system analyzed for each category. (The costs of the water extraction system can be defined as the costs paid by the farmer for groundwater). Figure (9) shows the components of the cost of groundwater extraction system in the agricultural sector, which include the cost of energy consumption used to operate the pumps, the basic cost of the 
pumps, the cost of maintaining pumps and the basic cost of the well. Most of these costs cannot be controlled except for energy costs (because they are subsidized by the government), which in some crops (wheat, for example) represents $59 \%$ of the cost of water extraction system. Any change in energy prices will have a strong impact on the cost of extracting water for the farmer and he must to deal with water more carefully. And maybe he have to move to less depleted groundwater crops in order to reduce payments and increase profits.

\subsection{Evaluating the Impact of High Energy Prices on the Continued Cultivation of Crops in the Study Area}

Energy prices in Saudi Arabia are heavily subsidized by the government. Therefore, the researcher found it necessary to study the effect of lifting subsidies on energy prices for agricultural sector. Figure (10) shows a comparison of the following elements:

1. Payments (includes all payments paid by the farmer since the land was rented through well drilling, equipment, labor, fertilizer, fallow land, pesticides, energy consumption, and harvesting costs).

2. Payments assume energy prices have been changed to global prices and other variables are stabilized (the global diesel price for year 2018 is about US \$ 0.63) (Makka, 2018).

3. Maximum payments (maximum costs): It is assumed that these costs could not be exceeded by the farmer, so that his profits would not be less than $10 \%$ of the price of the final product and by the assumption that the intermediaries have the same $10 \%$ of the price of the agricultural product. Accordingly, the maximum costs are calculated to reach $80 \%$ of the current price for agricultural product in the study area.
This comparison (Fig. 10) showed that raising energy prices for world prices will lead to the discontinuation of wheat cultivation and other fodderser crops and will significantly affect Alfalfa cultivation.

However, vegetable and date crops will be affected to a lesser extent by the higher cost of these crops compared with costs that include imposition of global energy prices. The researcher explains this by increasing the share of farmers and intermediaries' profits from the total final product price in the study area market (Fig. 8).

\subsection{Comparison of Prices of Agricultural Products with Alternative Opportunity Cost of Groundwater}

The researchers compared the prices of agricultural products in the study area with the alternative opportunity cost of groundwater used to irrigate these crops (assuming that the alternative opportunity cost of groundwater used for irrigation is the cost of water provided by the National Water Company in Saudi Arabia). The alternative product is 6 riyals per cubic meter (National Water Company, 2018).

Figure 11 shows a comparison of alternative opportunity cost of groundwater to irrigate each crop with average price of each crop per unit (SR / Hectare / year). The alternative cost of water to irrigate other fodder crops is estimated at 178,848 (SR / Hectare / year) compared to the average price of the fodders product $(11,703$ SR / Hectare / year). A comparison of alternative opportunity cost for irrigation water of Alfalfa crop is approximately about 161,004 (SR / Hectare / year) while the average price of the product in the market of the study area does not exceed 26,729 SR / Hectare / year. In addition, comparing the cost of alternative irrigation water to wheat crop is about 66,036 riyals per year, while the average price of the product in the market of the study area does not exceed 
9,367 SR / Hectare / year. These comparisons showed that cultivation of these crops is not economically feasible. While the average price of date crops represents $70 \%$ of alternative opportunity cost of water. For vegetables, it is remarkable that the average price of products in the market exceeds twice the alternative opportunity cost of vegetable irrigation water, but this does not mean the economic feasibility of vegetable crops. This comparison eliminated other agricultural costs (e.g. land, fertilizer, seeds, Pumps, generators and power).

\section{Conclusion}

The results of the descriptive analysis of field survey data for the most important agricultural crops in Wadi Al-Dawasir area showed that until this moment, the availability and accessibility of groundwater is not difficult. The study estimated that the cost paid by the farmer for groundwater is between SR
0.13 to 0.41 per cubic meter only (the percentage varies according to factors including groundwater depth, generator efficiency, crop type, pumping quantity, irrigated area, etc.). This cost is very low and is negligible if we compare it to alternative opportunity cost of water desalination by the National Water Company for the residential sector, which is up to 6 riyals / cubic meter (for the upper part of tariff of water bills).

The study also showed that the cost of energy consumption ranges from $18 \%$ to $60 \%$ of the cost paid by farmers for water (the percentage varies depending on factors such as groundwater depth, generator efficiency, crop type, pumping quantity, irrigated area, etc.). The study concluded that lifting subsidies on energy prices until reaching world prices will stop the cultivation of Alfalfa, other fodderser and wheat while continuing to cultivate vegetables and dates.

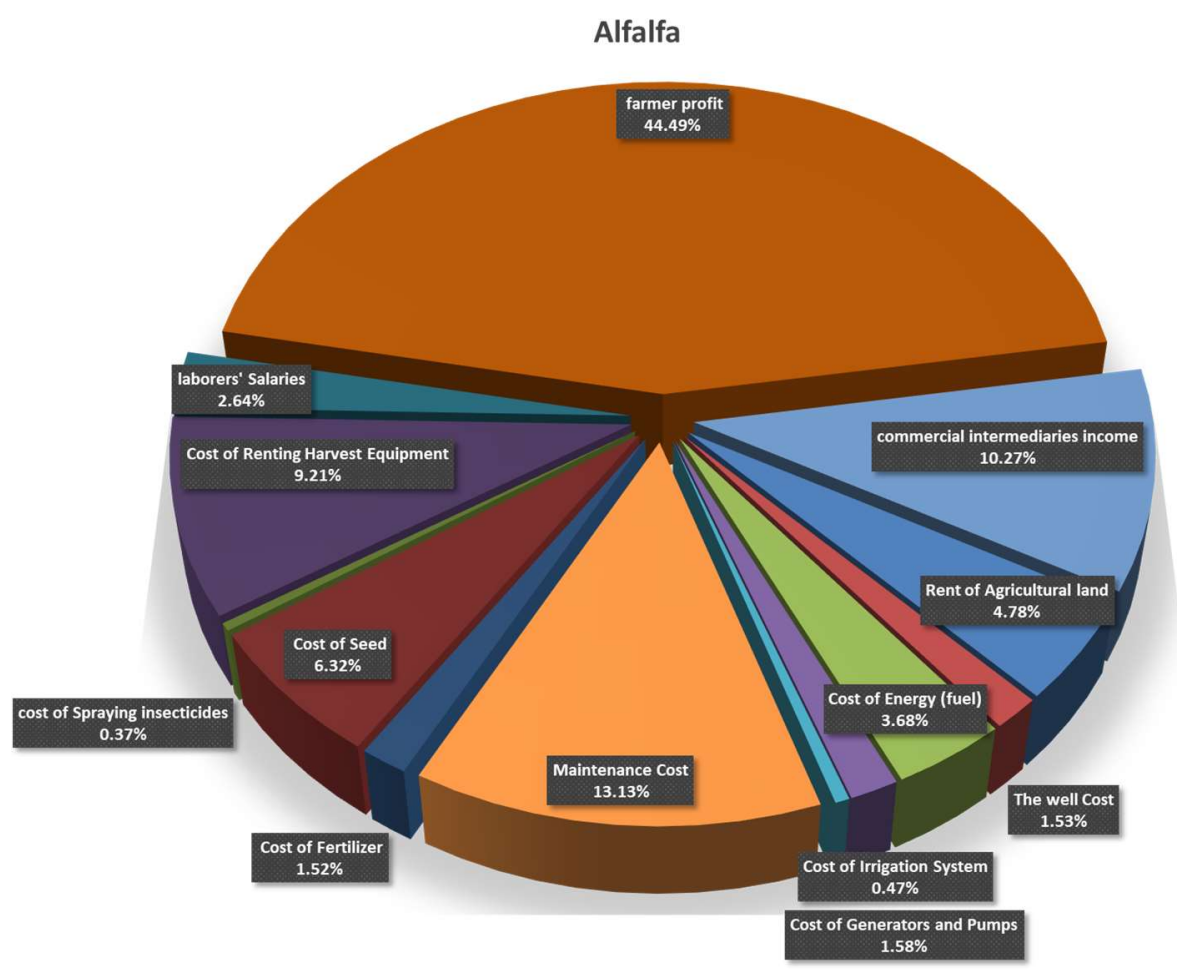

Fig. 2. Economic analysis of costs ratio of the Alfalfa crop price components. 


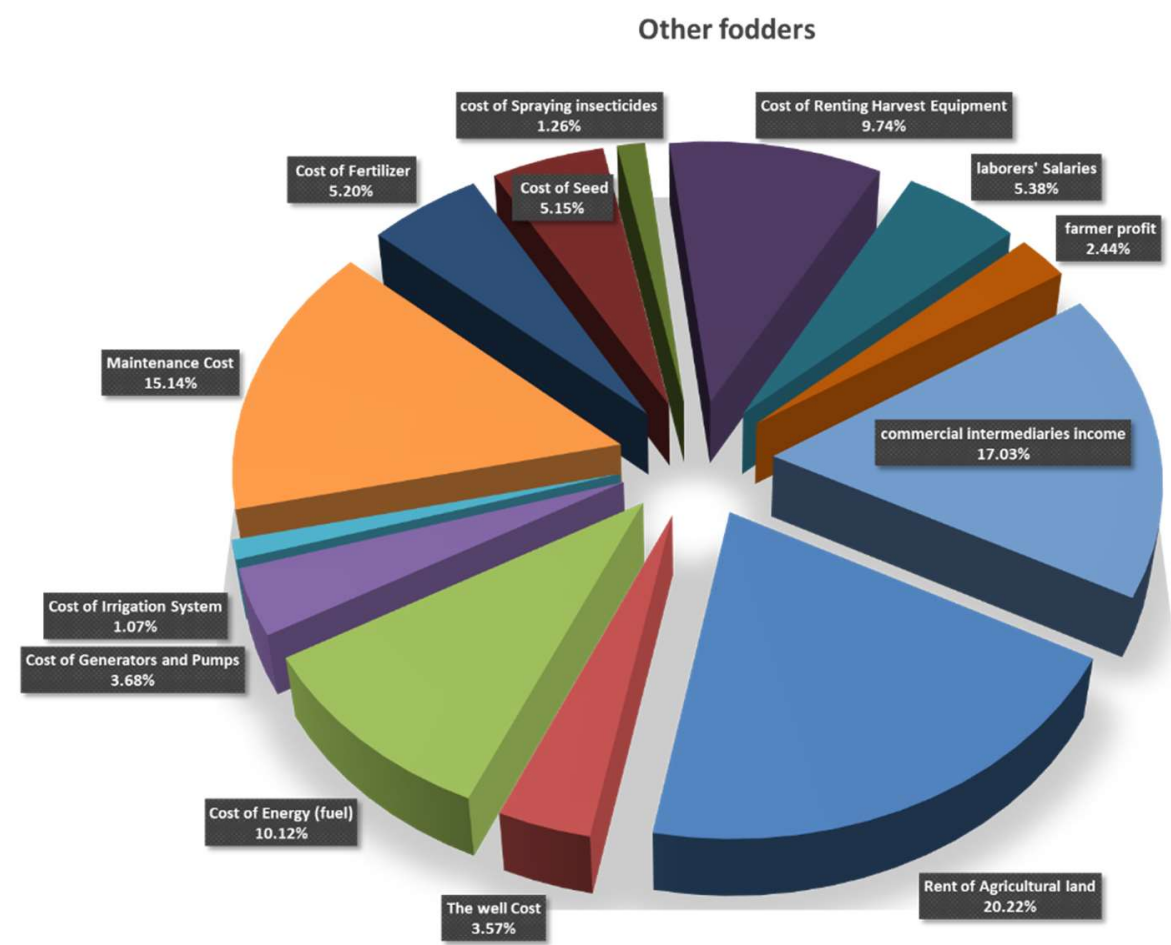

Fig. 3. Economic analysis of costs ratio of other fodders crop price components.

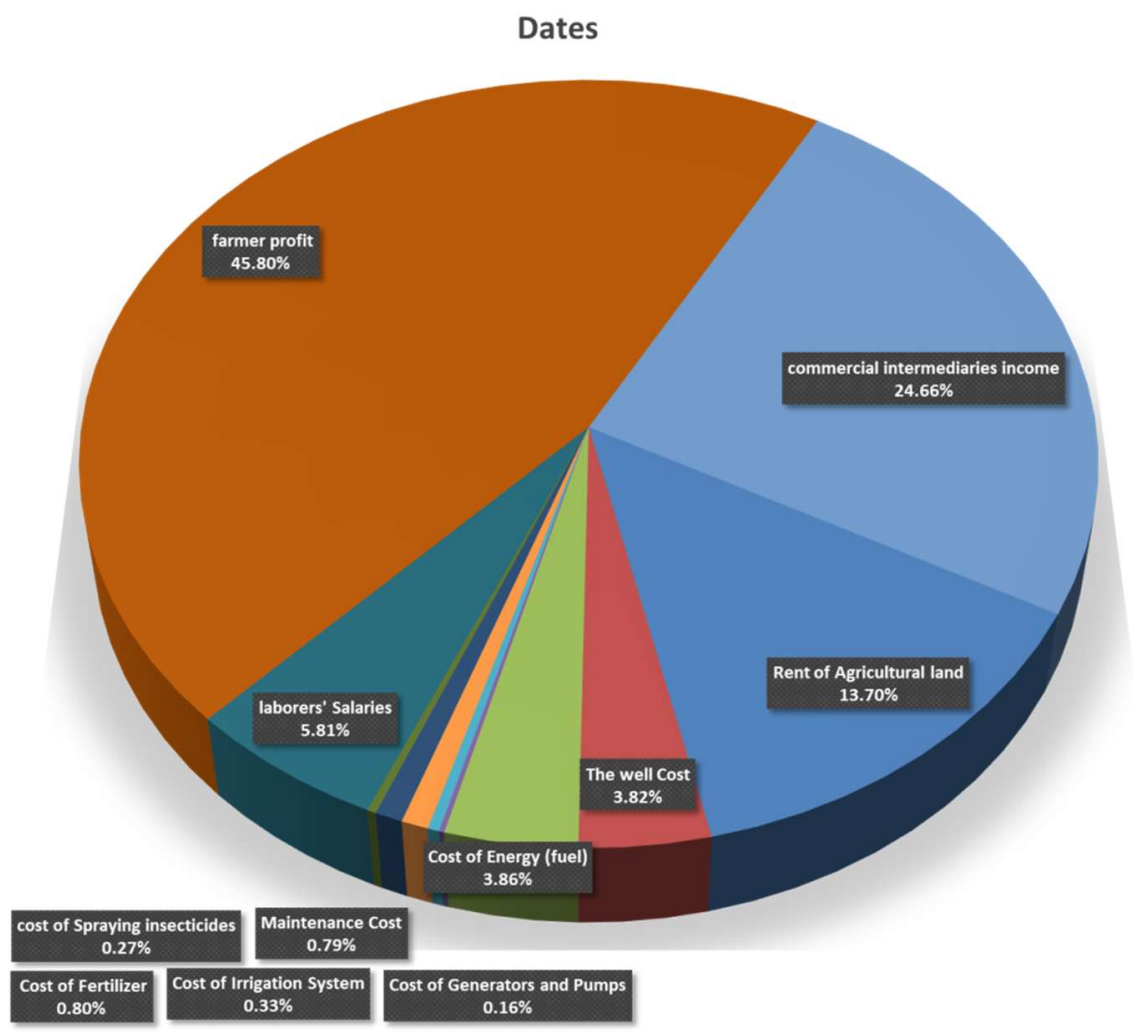

Fig. 4. Economic analysis of costs ratio of date crop price components. 


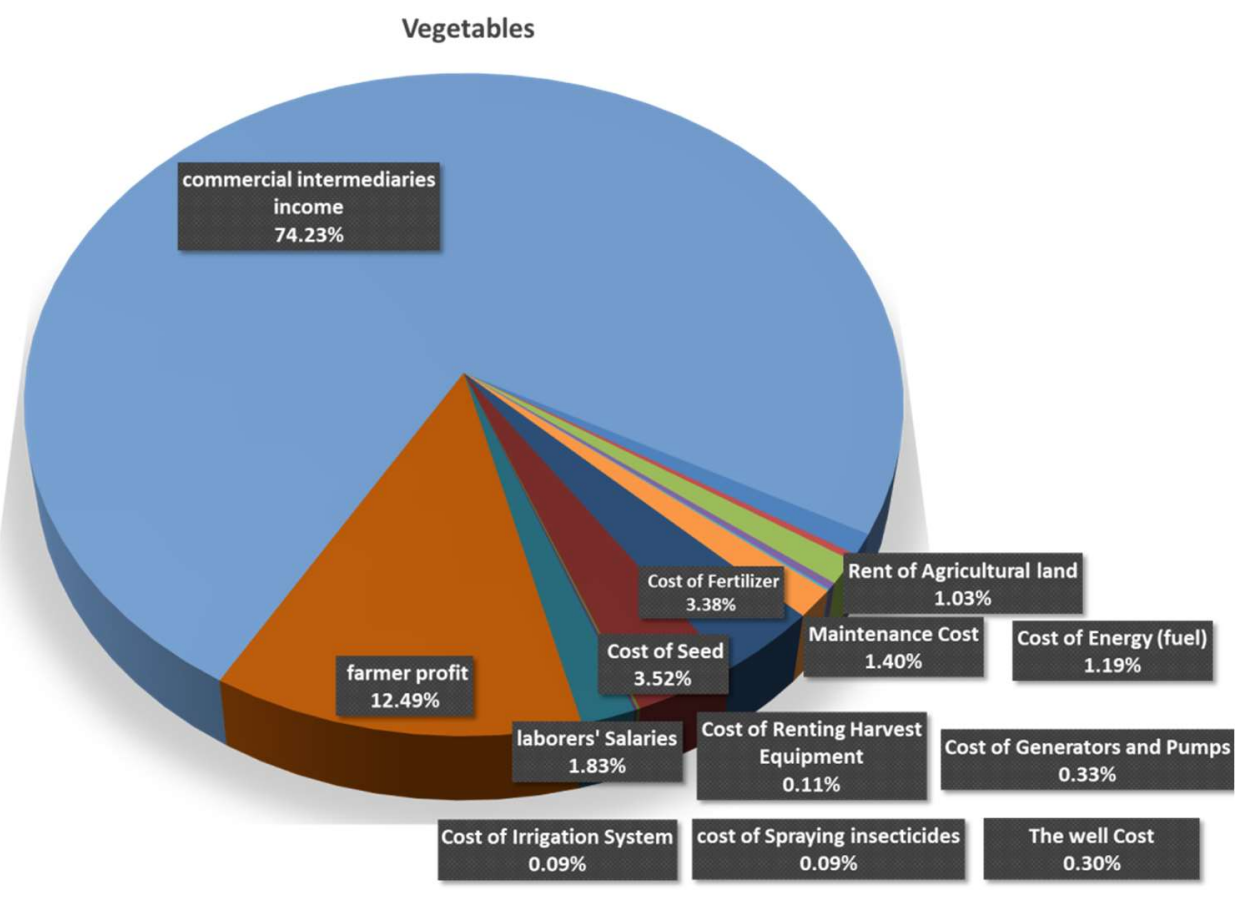

Fig. 5. Economic analysis of costs ratio of vegetables crop price components.

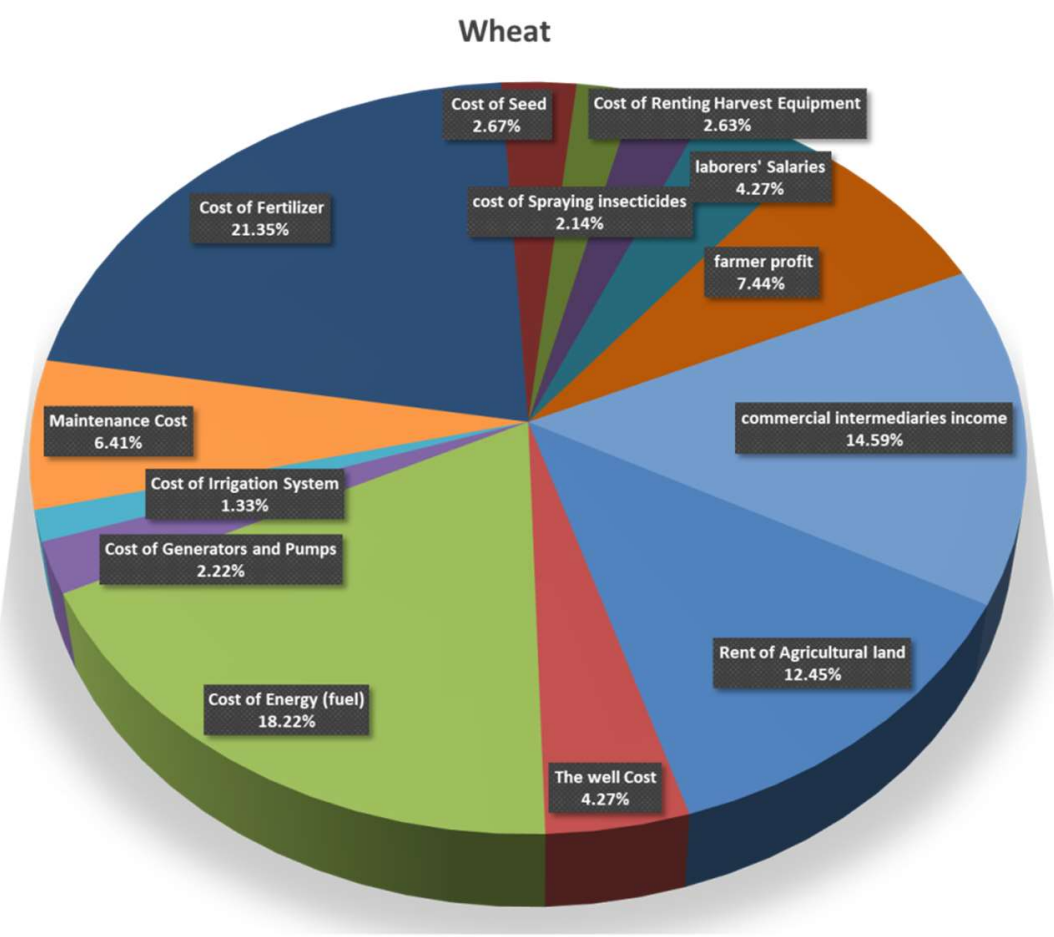

Fig. 6. Economic analysis of costs ratio of wheat crop price components. 


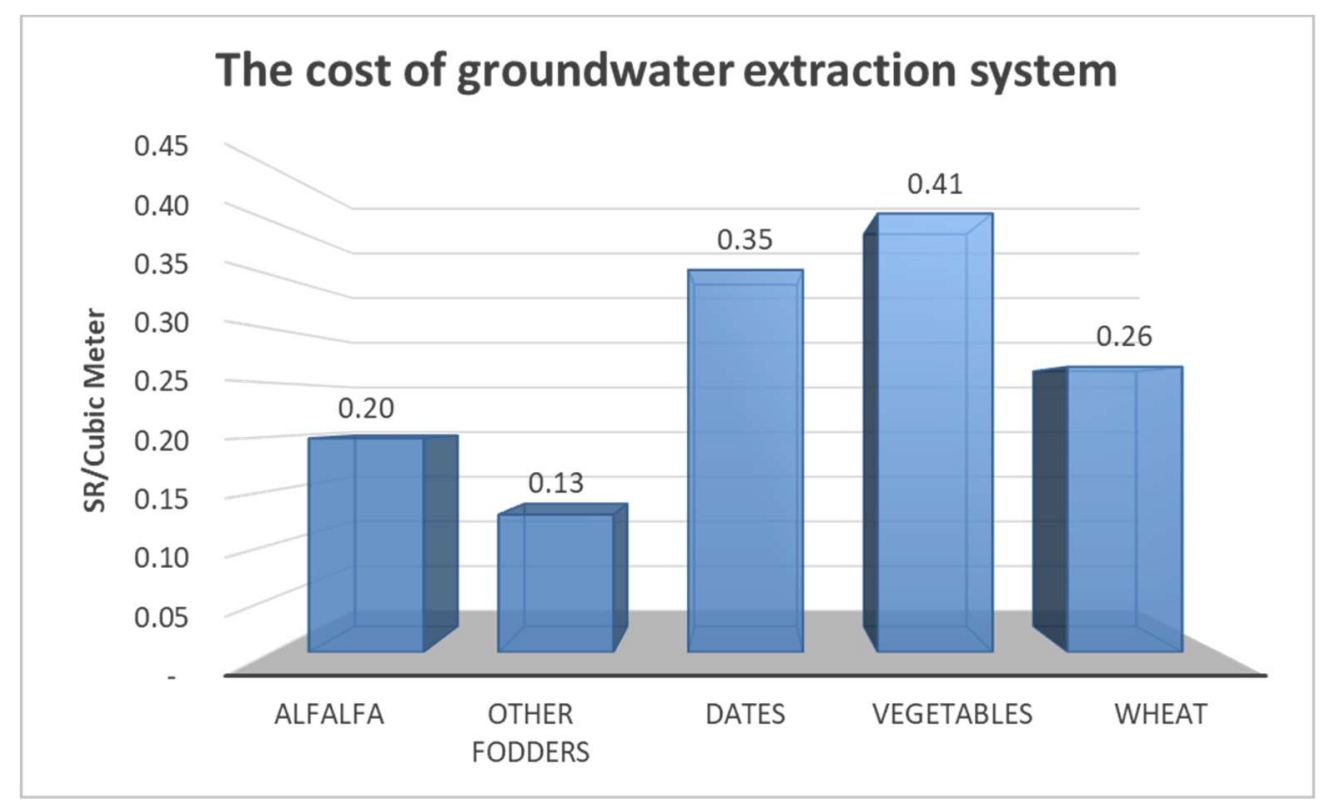

Fig. 7. The cost of groundwater extraction system.

Percentages of the components of the price of each crop

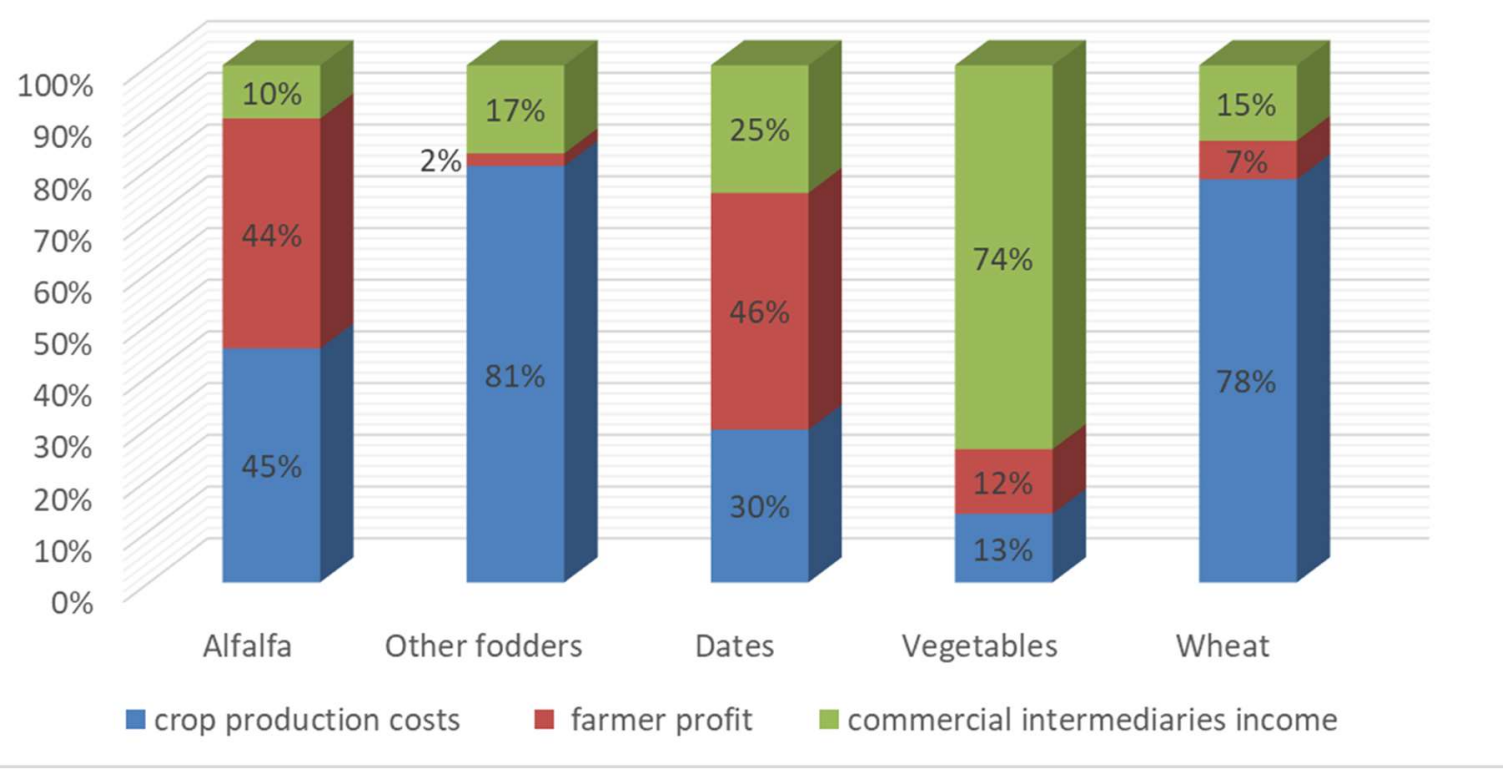

Fig. 8. Percentages of the components of the price of each crop. 


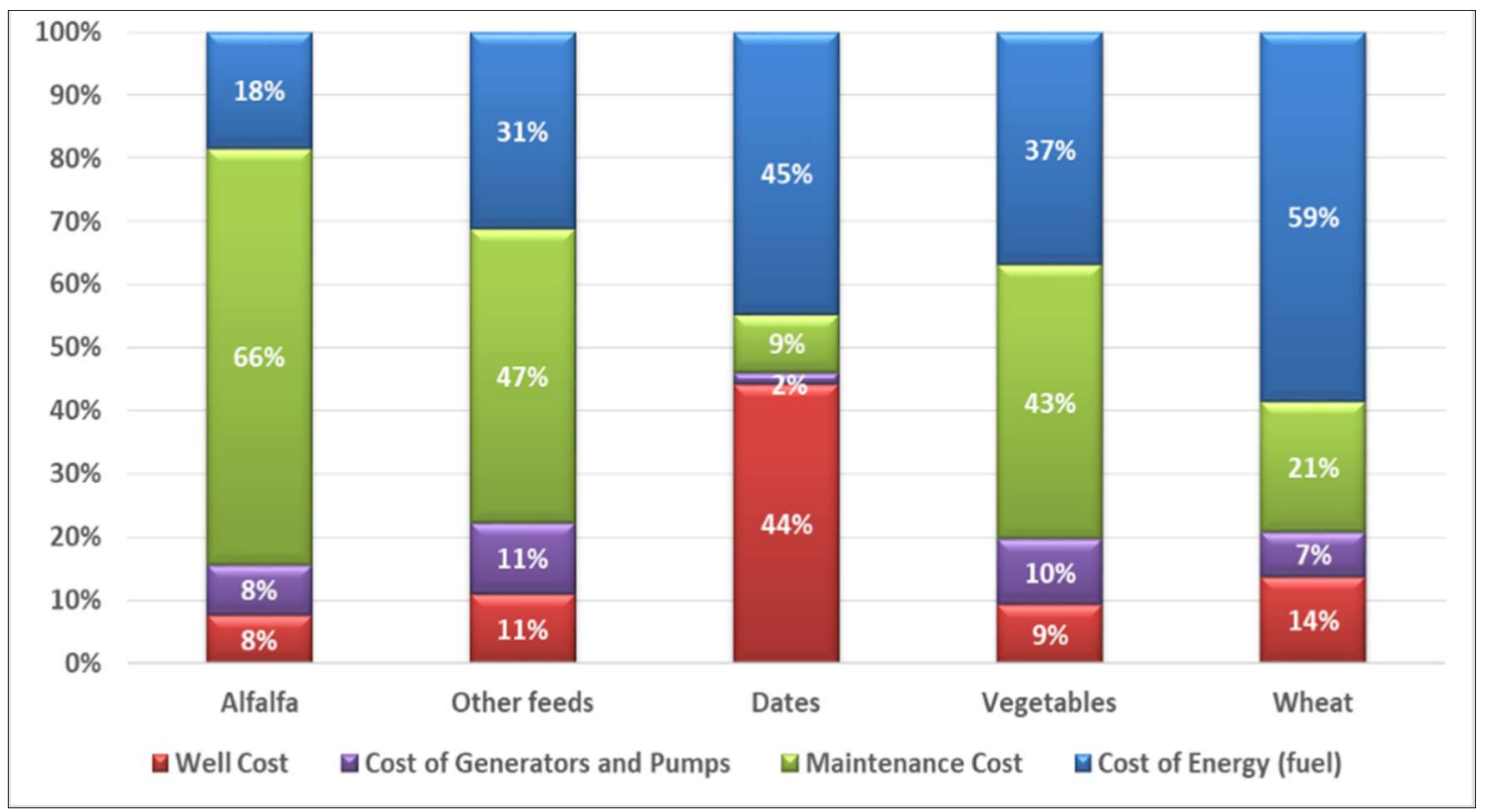

Fig. 9. Percentages of components of the cost of groundwater extraction system to cultivate the most important crops in the study area.

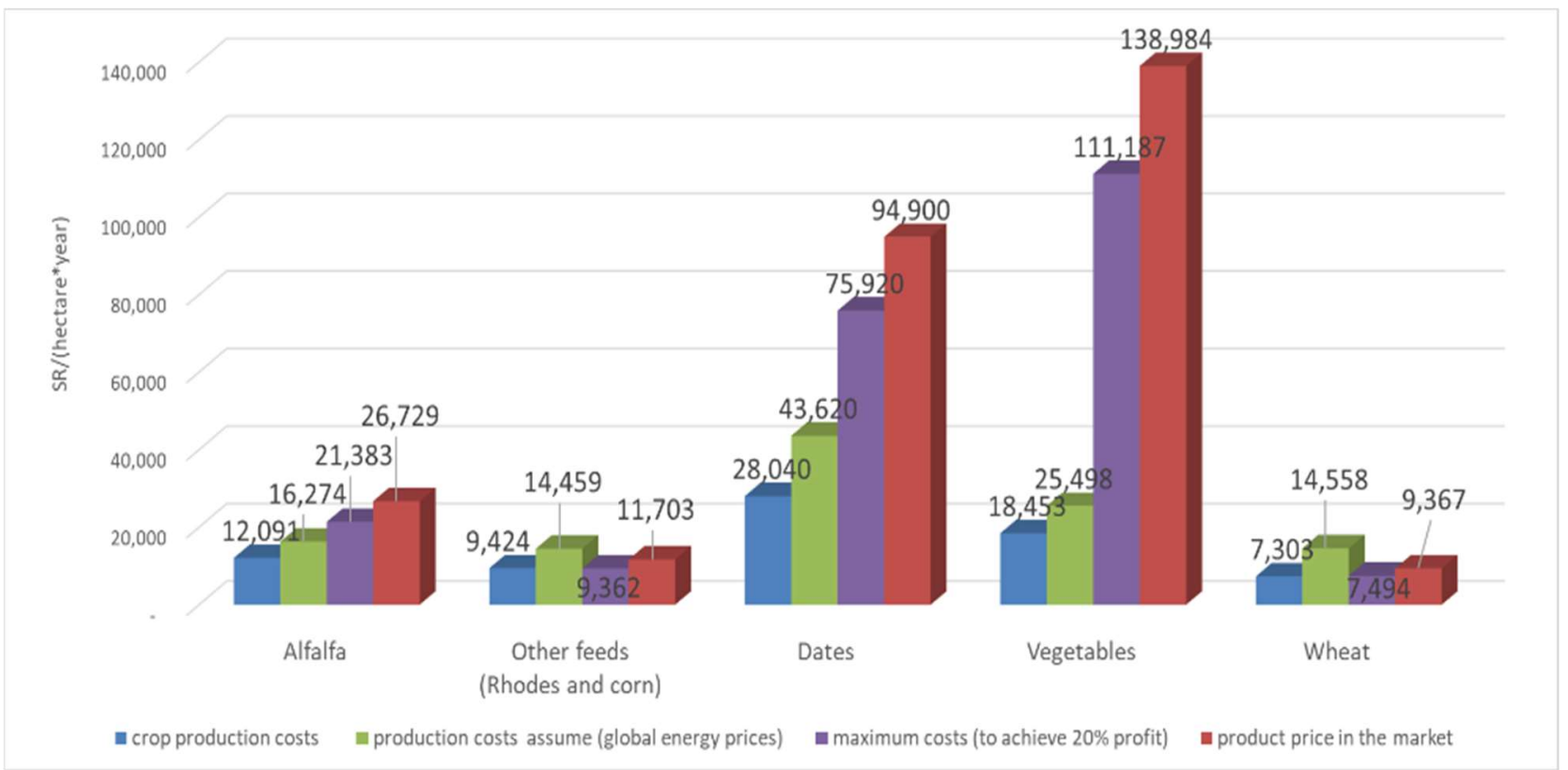

Fig. 10. Comparison of the impact of high energy prices on agricultural crops in the study area. 


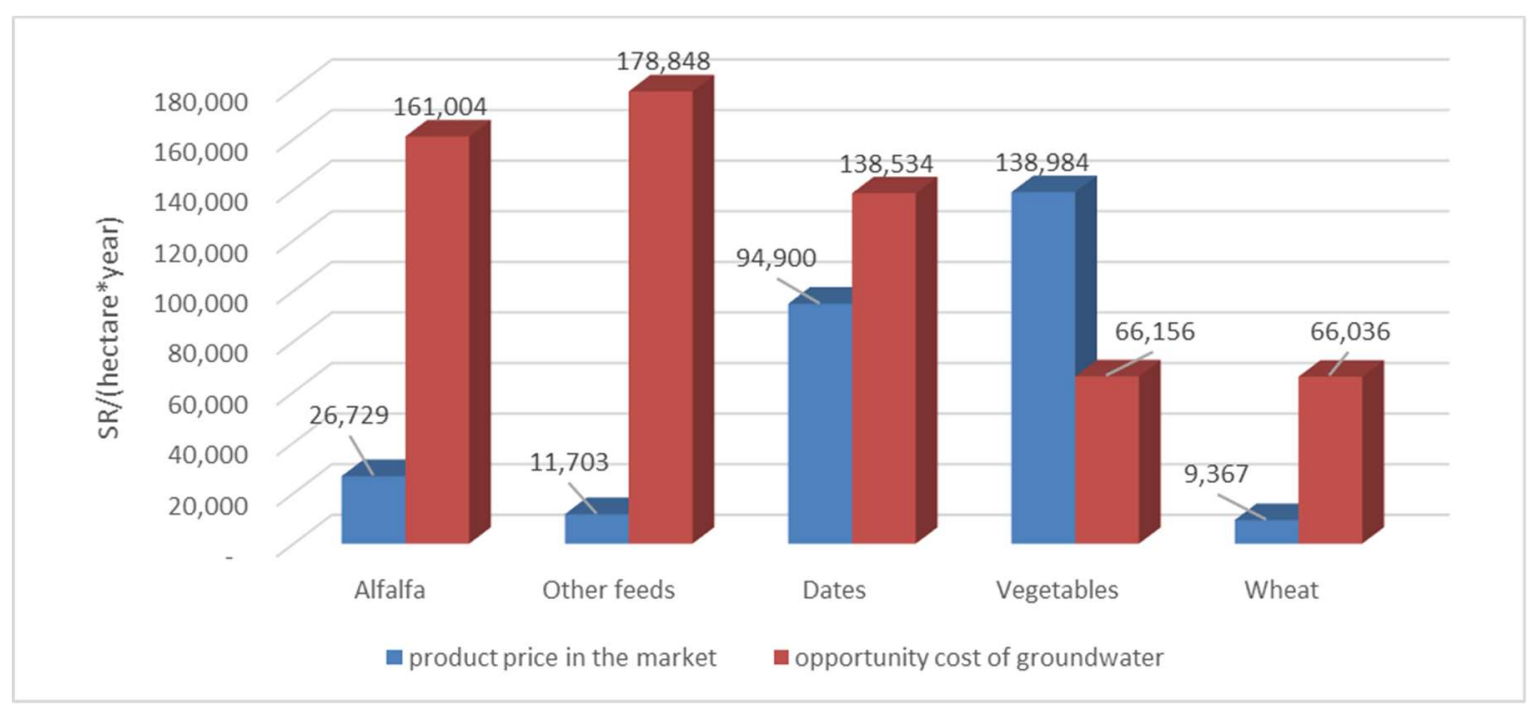

Fig. 11. Comparison of the average prices of main crops of the study area with the alternative opportunity cost of groundwater used in irrigation.

\section{References}

Alhassan, A. A. , McCluskey, A., Alfaris, A. and Strzepek, K. (2015) Scenario Based Regional Water Supply and Demand Model: Saudi Arabia as a Case Study, International Journal of Environmental Science and Development, 7: 46-51.

Abdelfattah, E. H. (2013) Discovering Statistical Analysis and Bootstrap using IBM-SPSS, Khawarizm Acadenic, Jeddah.

Cornish, G., Bosworth, B., Perry, C.J. and Burke, J. (2004) Water charging in irrigated agriculture :An analysis of international experience, Food and Agriculture Organization of the United Nations, Rome.

Elhag, M. and Bahrawi, J. A. (2017) Realization of daily evapotranspiration in arid ecosystems based on remote sensing techniques, Geosci. Instrum. Method. Data Systems, 6: 141-147.

Elhag, M. (2016) Evaluation of Different Soil Salinity Mapping Using Remote Sensing Techniques in Arid Ecosystems Saudi Arabia, Journal of Sensors: Volume 2016, Article ID 7596175.

Gesellschaft T. Z. and Dornier C. (2010 a), Studies of the water resources of the Wajid aquifer and the aquifers above it (main report), Water Resources Development Department, Ministry of Environment, Water and Agriculture:1.

Gesellschaft T. Z. and Dornier C. (2010 b), Studies of the water resources of the Wajid aquifer and the aquifers above it (Water demand for agricultural sector), Water Resources Development Department, Ministry of Environment, Water and Agriculture:6.
Global Water Partnership (2000) Integrated water resources management, Background Papers, Technical Advisory Committee, Denmark.

Kim, A. and Der Beek, H.V. (2018) A Holistic Assessment of the Water-for-Agriculture Dilemma in the Kingdom of Saudi Arabia, Center for International and Regional Studies, Georgetown University, Occasional Paper No. 19.

Ministry of Environment, Water and Agriculture (2013), Agricultural areas of crops in the cities of Saudi Arabia for the period (2000-2013).

Makkah N. (2018), The price of gasoline in Saudi Arabia، from: http://makkahnewspaper.com/, Access date, January 03, 2018.

Napoli, C., Wise, B., Wogan, D. and Yaseen, L. (2016) Policy Options for Reducing Water for Agriculture in Saudi Arabia, King Abdullah Petroleum Studies and Research Center.

Napoli, C. and Téllez, B.G. (2016) Energy for Water in Agriculture: A Partial Factor Productivity Analysis, King Abdullah Petroleum Studies and Research Center.

National Water Company (2018), Information about tariff، from:

https://www.nwc.com.sa/Arabic/Pages/NewTarrifCalculat or.aspx, Access date, January 21, 2018.

Ouda, O.K.M. (2013) Towards Assessment of Saudi Arabia Public Awareness of Water Shortage Problem, Journal of Resources and Environment, 3: 10-13.

Ray, I. (2002) Farm-level incentives for irrigation efficiency: some lessons from an Indian canal, Issue on Incentives and Trading in Water Resource Management, 121: 64-71. 
تقييم لتأثثر العو امل الاقتصادية المكونة لسعر المحصول على استمر ار الزراعة في و ادي الدواسر ، المملكة العربية السعودية

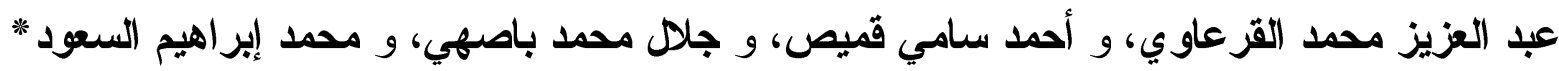

قسم علوم وإدارة موارد المباه، كلبة الأرصاد والبيئة وزراعة الدناطق الجافة، جامعة الملك عبد العزيز،

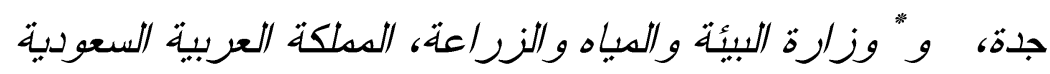

garawany5000@yahoo.com

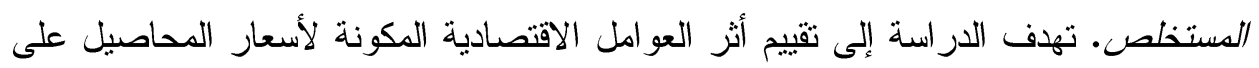

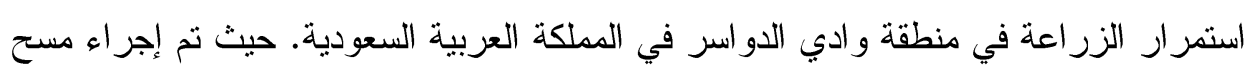

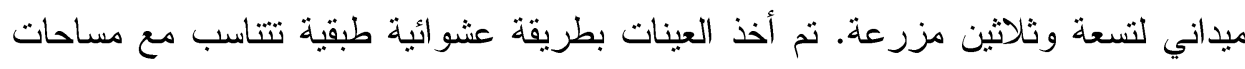

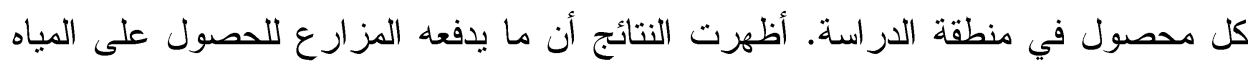

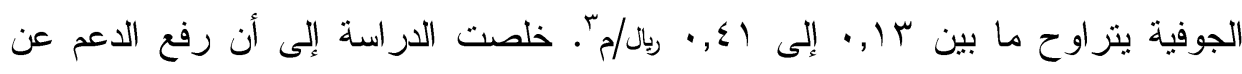

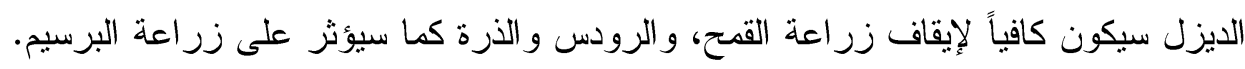

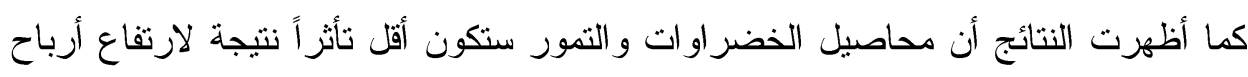
المز ارعين والوسطاء بالنسبة لنكلفة الإنتاج.

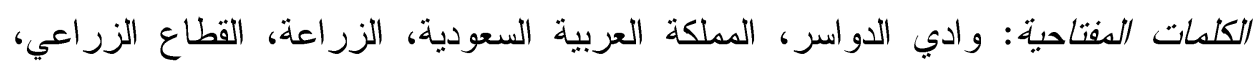
تكلفة مياه الري، تكلفة المياه الجوفية. 
